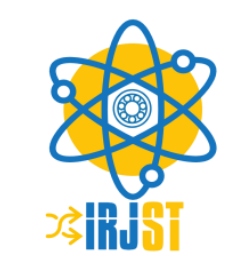

Available online at https://www.irjst.com/

International Research Journal of Science and Technology

ISSN: 2707-3955

DOI: https://doi.org/10.46378/irjst.2020.010405

\title{
Effect of Antibacterial Agents on the Microbial Flora of Some Fruits and Vegetables.
}

\section{Omorodion Nnenna and Oriji Gift}

University of Port Harcourt, Department Of Microbiology, P.M.B. 5323, Port Harcourt Rivers state, Nigeria.

\begin{tabular}{llll}
\multicolumn{2}{l}{ Paper Status } & & \\
& Received & Aug & 2020 \\
Accepted & $:$ & Sep & 2020 \\
Published & $:$ & Sep & 2020
\end{tabular}

\section{Abstract}

Six samples of fruits (apple, banana, mango, orange, pineapple and watermelon) and six samples of vegetables (cabbage, carrot, cucumber, lettuce, potato and tomato) were purchased from wokem market in Choba town PH, Rivers State and microbiological analysis were carried out these fruits and vegetables samples and the effects of the antimicrobial agents (Ethanol and Hydrogen peroxide) on the microbial load. The Total viable count, Total coliform count and Escherichia count were determined via standard microbiological methods. The Total viable count ranged from $4.1 \times 1010^{6}$ to $1.0 \times 10^{7} \mathrm{cfu} / \mathrm{g}$ Total coliform count from $4.5 \times 10^{7}$ to $1.5 \times 10^{6} \mathrm{cfu} / \mathrm{g}$ nd the E.coli count ranged from $5.1 \times 10^{2}$ to $1.0 \times 10^{2} \mathrm{cfu} / \mathrm{g}$. The Total viable count for apple ranged between to $5.1 \times 10^{7}$ to $2.07 \times 10^{9}$, Cabbage $1.45 \times 10^{9}$ to $4.9 \times 10^{7}$, banana $1.10 \times 10^{9}$ to $5.9 \times 10^{7}$, cucumber $1.82 \times 10^{8}$ to $6.0 \times 10^{7}$. The microorganisms isolated were Escherichia coli $42 \%$, Staphylococcus aureus $30 \%$, Pseudomonas spp 18\%, Bacillus spp, $6 \%$ and

Key Words

Antimicrobial

Fruits

Microbial Flora

Vegetables Serratia spp, $2 \%$. Hydrogen perioxide had a high pathogen reduction rate than ethanol.The isolation of $E$ coli and other pathogenic microorganisms indicates the presences of faecal contamination and the poor hygienic production, storage and transport system. Fruits and vegetables should be properly handled from their seeds planted in the farm to the matured ones sold in the market

Copyright (c) 2020: Omorodion Nnenna and Oriji Gift. This is an open-access distribution, and reproduction in any medium provided Access article distributed under the Creative Commons Attribution License the original work is properly cited License, which permits unrestricted use.

Citation: Omorodion Nnenna and Oriji Gift. "Effect of Antibacterial Agents on the Microbial Flora of Some Fruits and Vegetables". International Research Journal of Science and Technology, 1 (4), 299-304, 2020.

\section{Introduction}

Fresh cut fruits and vegetables are "any fresh fruit or vegetable or any combination thereof that has seen alterations from its original form, but remains in a fresh state [1]. Fresh-cut fruits and vegetables provides consumer with ready -to-eat produce that is one of several convenient, nutritious and fresh-like tasting with many health values [2].

The contamination of fresh produce is of serious public health implication, as food borne illness are increasingly becoming a global public health problem leading to an increased amount of morbidity and mortality annually worldwide [3].

\footnotetext{
* Corresponding Author: Omorodion Nnenna

University of Port Harcourt, Department of Microbiology,

Nigeria.

Email: nnennaomorodion@gmail.com, nnenna.omorodion@uniport.edu.ng
}

Microbial contamination of fruits and vegetables occurs on a regular basis due to some factors like; contact with soil, dust, globalization of food supply, introduction of pathogens into new geographical areas through import, use of untreated waste water and water supplies contaminated with sewage, manure as fertilizers, irrigation and various agronomic practices, post-harvest handling, and hygienic conditions of preparation in food service or home settings [4]. There are a number of microorganisms which are associated with many of these fresh fruits and vegetables from the planting stage to the consumption stage at the market. They are; Escherichia coli 0157:H7, next to Salmonella spp., Listeria monocytogenes, Aeromonas spp., Staphylococcus spp., Streptococcus spp., Vibrio spp. and Pseudomonas spp, Shigella spp. E. coli is associated with apple cider, sprouts, lettuce, radish sprout, carrot is associated with Pseudomonas spp, Erwinia spp, Xanthomonas spp, tomatoes is associated with Pseudomonas spp, Bacillus spp, Lactic acid bacteria [5]. Many fruits and vegetables presents 
nearly ideal conditions for survival and growth of many types of microorganisms. The Objective of the study is to determine the sanitary quality of fruits and vegetables using Total Viable Count (TVC) and Total coliform count and to determine the effects of antimicrobial agents on the microbial load of the fruit and vegetables.

\section{Materials and Methods}

\subsection{Source, Collection and Prparation of Samples}

Six fresh fruits and six vegetables were purchased from Wokem market in Choba Town, PH, Rivers State,Cabbage., Banana., Cucumber. Mango, Carrot. Orange., Lettuce.,Pineapple, Tomatoe. Watermelon. Potatoe.

\subsection{Ethanol Sample Preparation}

$70 \%$ of ethanol was prepared by pouring $300 \mathrm{ml}$ of water in $700 \mathrm{ml}$ of ethanol and was used to rub on the surfaces of the samples and allowed to dry for 5 minutes.

\subsection{Hydrogen Peroxide Sample Preparation}

$3 \%$ of hydrogen peroxide was prepared by mixing 1 and $1 / 4$ cups of $35 \%$ hydrogen peroxide with 14 and $3 / 4$ cups of water. It was rubbed on the surfaces of the samples and allowed to dry for 5 minutes.

Isolation And Identification Of Escherichia coli From various samples before and after application of Antimicrobial Agent. 25g of sample was added to $225 \mathrm{ml}$ of buffered peptone water (BPW). All the samples were incubated at 16-20 hours (overnight) at $37^{\circ} \mathrm{C}$ from the pre-enriched culture (Stock culture), serial dilution was carried out and $0.1 \mathrm{ml}$ was plated out from dilutions $10^{-1}$ and $10^{-2}$ in duplicates on Eosin Methyl Blue (EMB) agar by by the spread plate method and incubated at $37^{\circ} \mathrm{C}$ for 24 hours

Total aerobic counts and Total coliform counts of the various samples before and after application of antimicrobial agents. Serial dilution was carried out and $0.1 \mathrm{ml}$ was plated out from dilution $10^{-5}$ and $10^{-6}$ on Plate Count Agar and dilution $10^{-3}, 10^{-4}$ for total coliform count on MacConkey agar and incubated for about 24 hours and checked for distinct colony. Distinct colonies picked from the different agar plates were sub-cultured on nutrient agar to obtain pure cultures. Following incubation, the isolates obtained were inoculated on nutrient agar slants in bijou bottles for preservation and identification using various biochemical tests. Counts between 30-300 colonies was accepted for a single plate. After the incubation period, representing colonies from both the total viable count and of Escherichia spp, colonies were picked from the different plates based on different colonial characteristics, colonies are sub-cultured onto nutrient agar for purification and transferred on nutrient agar slants and incubated at $37^{\circ} \mathrm{C}$ for 24 hours. The isolates were characterized presumptively by colonial morphology, pigmentation, Gram staining, biochemical testing.

\section{Results}

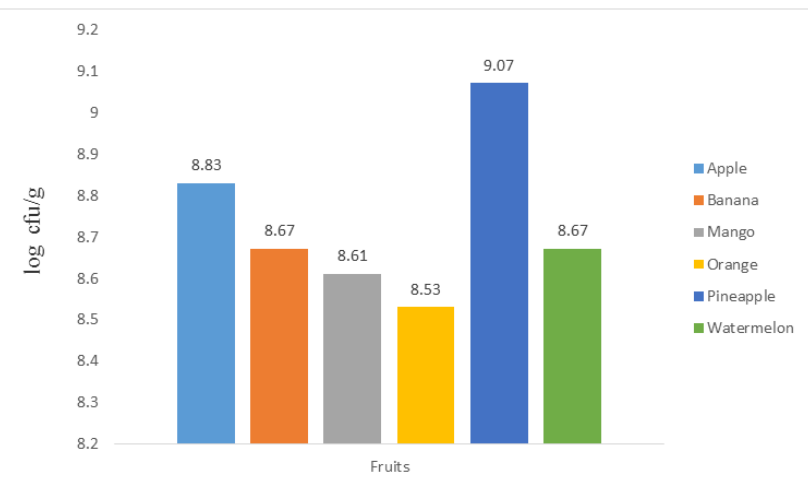

Figure 1.Total viable count for fruits before application of antimicrobials

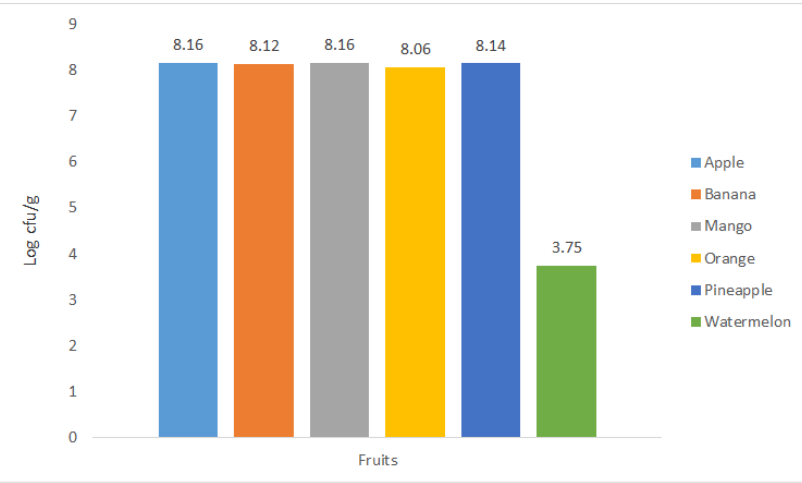

Figure 2. Total viable count of fruits after the application of ethanol

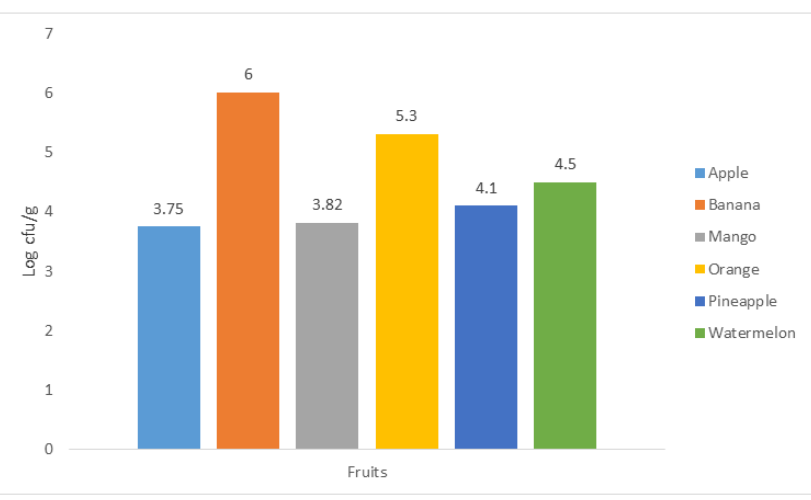

Figure 3. Total viable count of fruits after application of hydrogen peroxide 


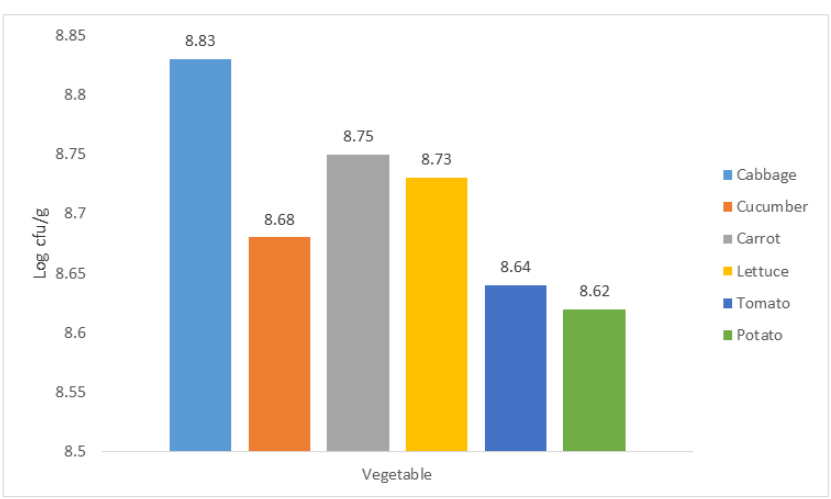

Figure 4. Total viable count of vegetables before application of antimicrobials

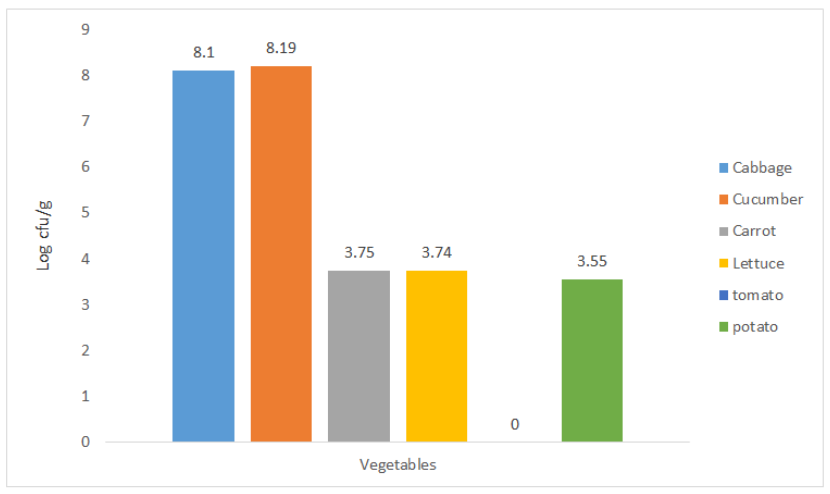

Figure 5. Total viable count of vegetables after application of ethanol.

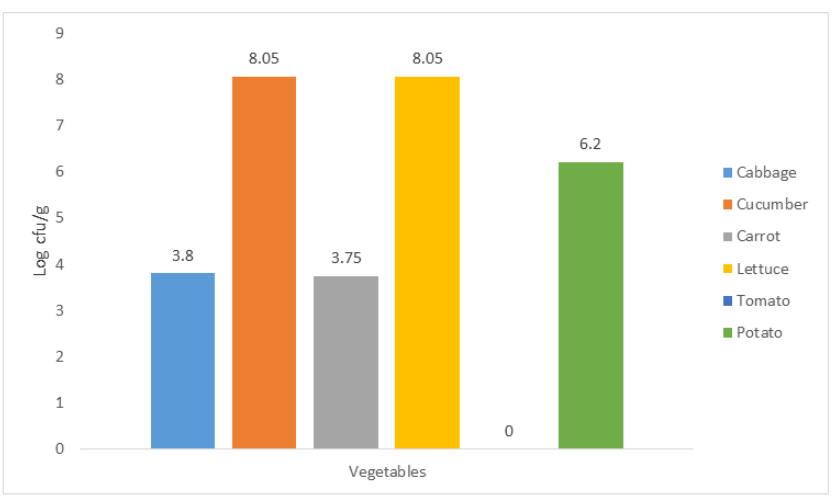

Figure 6. Total viable count of vegetables after application of hydrogen peroxide

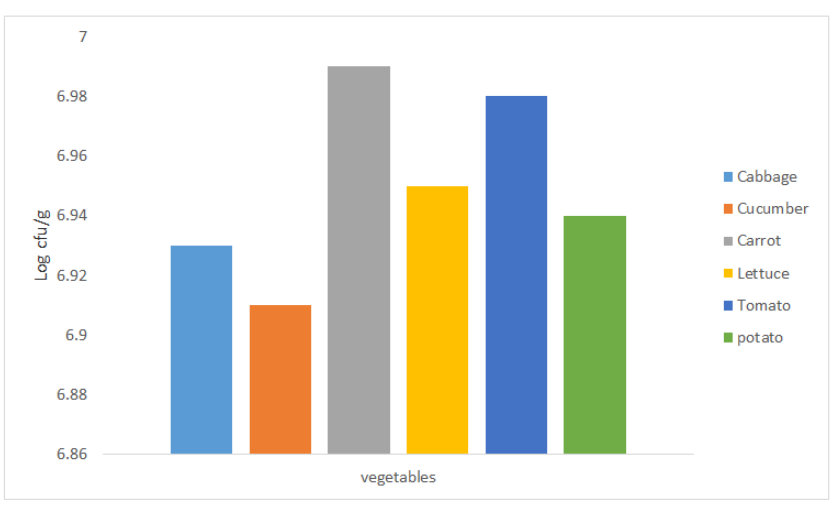

Figure 7. Total coliform count for fruits before application of antimicrobial agents

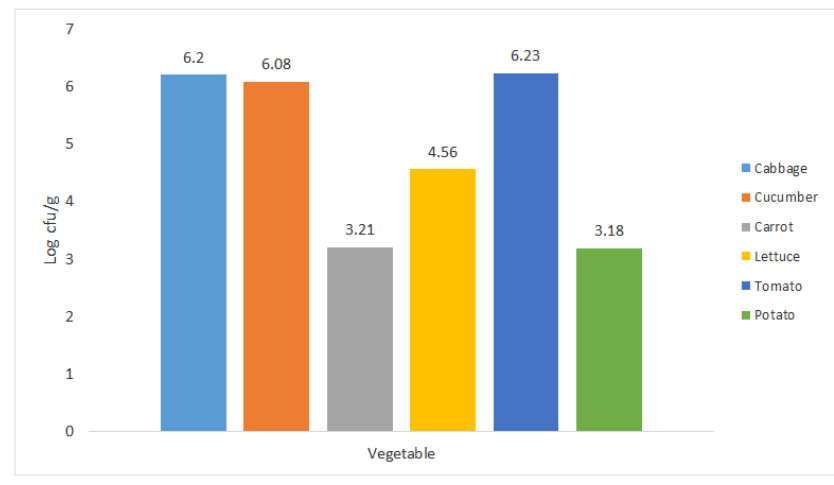

Figure 8.Total coliform count of vegetables after application of ethanol

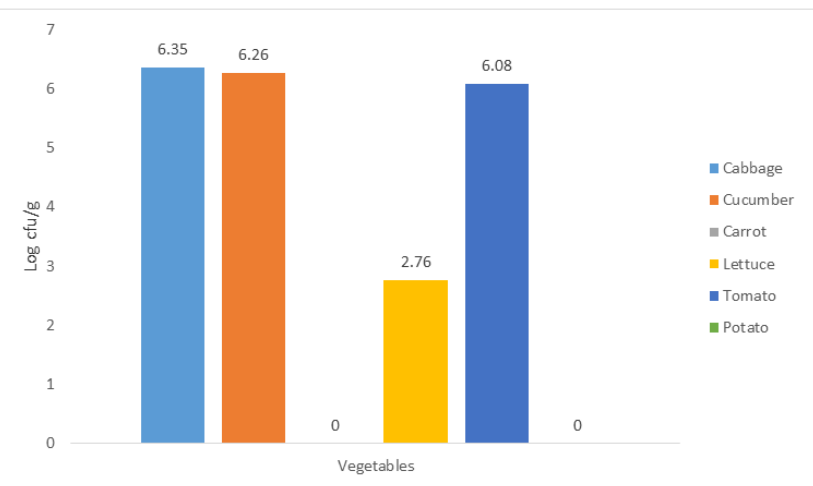

Figure 9. Total coliform count of vegetables after application of hydrogen peroxide

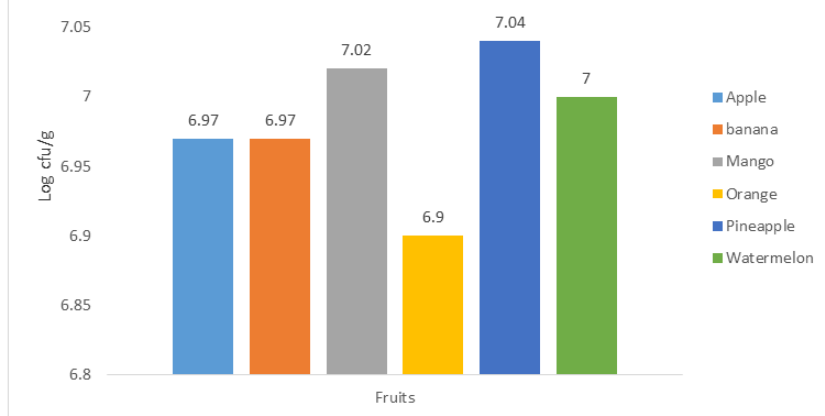

Figure10.Total coliform count for fruits before antimicrobial application.

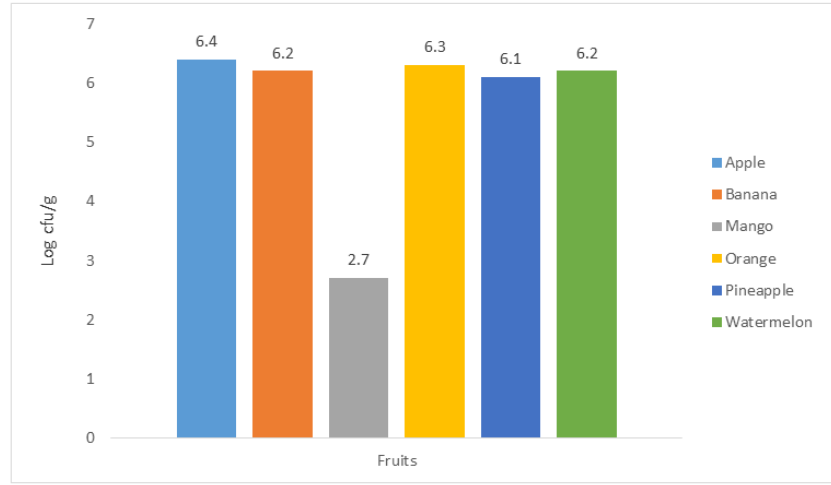

Figure 11. Total coliform count for fruits after antimicrobial ethanol 


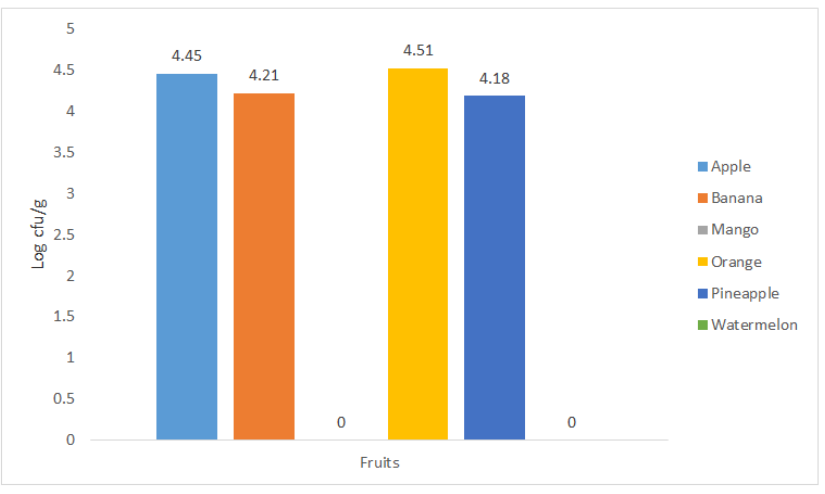

Figure 12. E.coli growth on fruits before application of antimicrobials

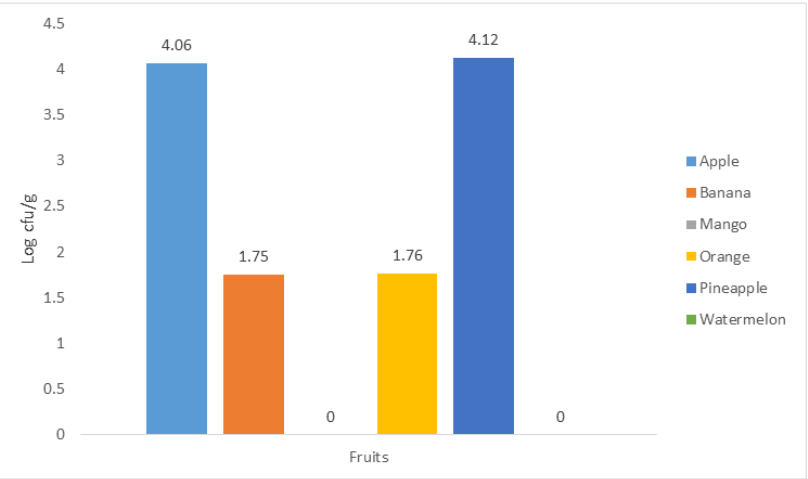

Figure 13. E.coli growth on fruits after application of ethanol

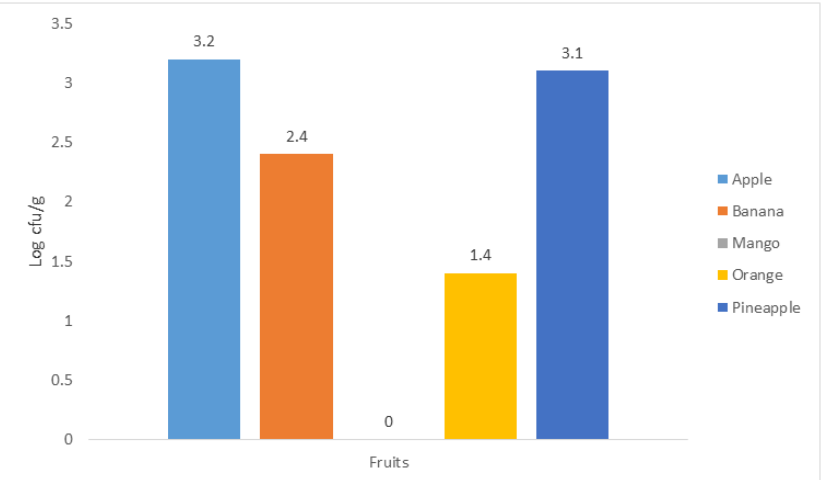

Figure 14. E.coli count on fruits after application of hydrogen peroxide.

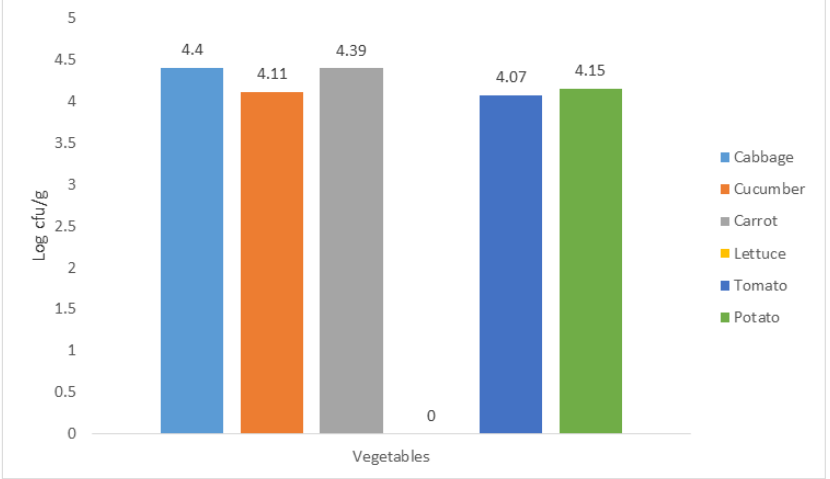

Figure 15. E coli growth on vegetables before application of antimicrobial

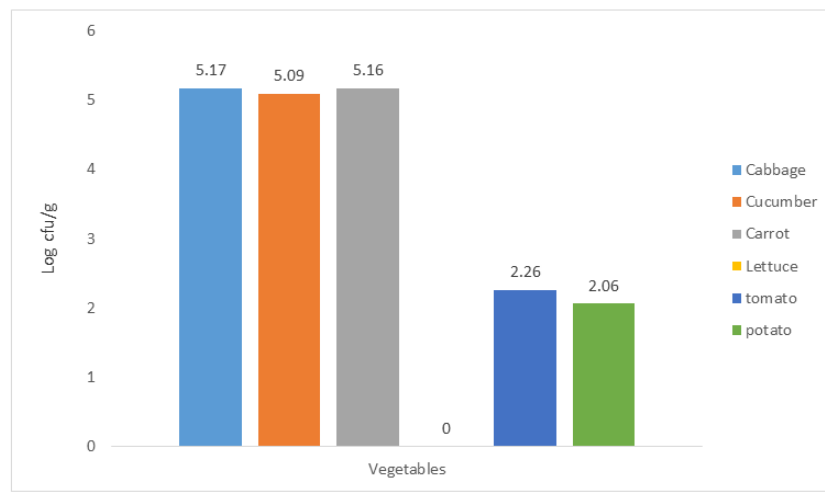

Figure 16. E.coli growth on vegetables after application of ethanol.

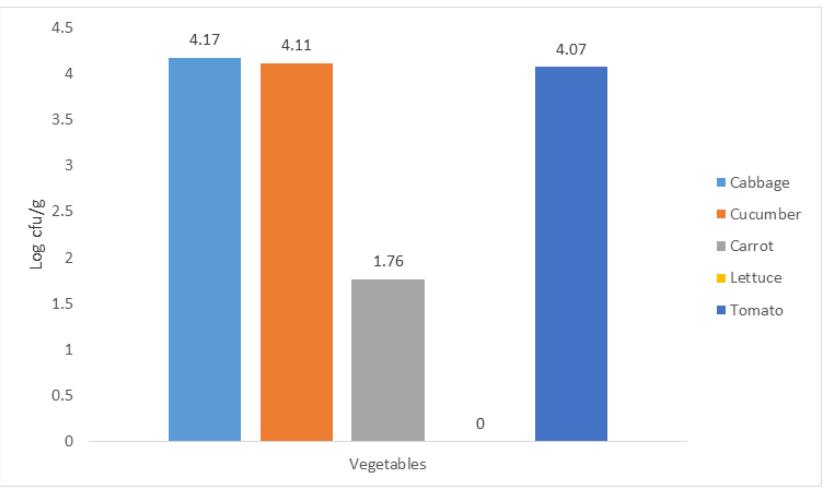

Figure 17. E.coli count on vegetables after application of hydrogen peroxide.

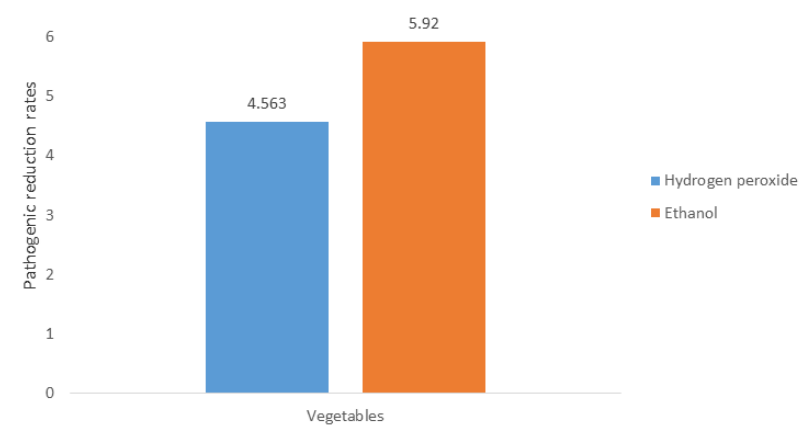

Figure 18. Comparison of antimicrobial effects on Vegetables.

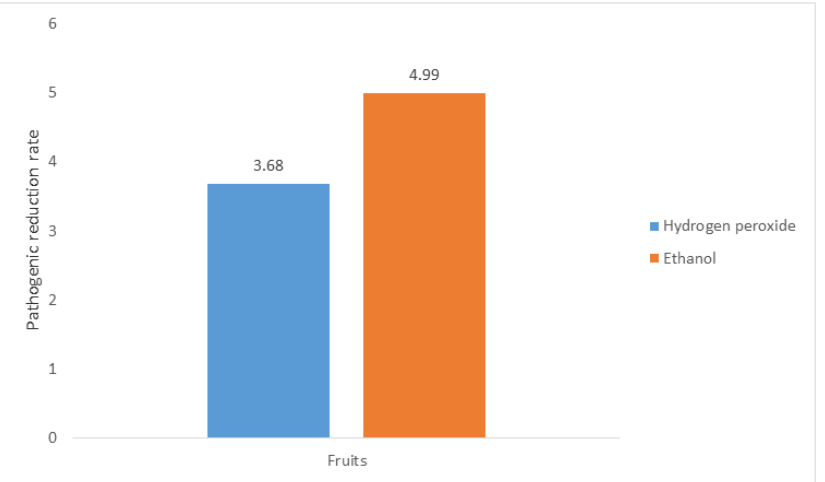

Figure 19. Comparison of antimicrobial effects on Fruits

\section{Discussion and Conclusion}

The organisnms present in friuts and vegatbles is an indication of the sanitary quality of the cultivation 
water, havesting, transportation, storage, and processingof the produce [6]. All the bacteria isolated in this study have been isolated from fruits and vegetables in other studies, both in Nigeria and elsewhere [7-8]. The high bacteria counts observed for the fruits and vegetables in this study are in agreement to those obtained in other studies in Nigeria [8-9] .The number of recorded outbreaks of human infections linked with the consuming raw fruits and vegetables has increased in recent years [10-11]. The results of the effect of chemical treatments on microbial load of fruits and vegetables indicates that each of the chemicals reduced microbial count to various degrees. Although a wide range of different agents are available for sanitizing fresh produce, their efficacy vary and none are able to completely eliminate pathogens. In this study hydrogen perioxide had a high microbial reduction rate on fruits and vegetable, when compared with ethanol [12]. Hydrogen peroxide (H2O2) have a lethal or inhibitory effect on microorganisms, which is dependent on the $\mathrm{pH}$, temperature and other environmental factors.In this study, higher microbial contamination has been noticed in orange and apple for the fruits while for the vegetables, cabbage and carrot had a higher contamination. E. coli count ranged from $\left(5.1 \times 10^{-2} \mathrm{cfu} / \mathrm{g}\right)$ to $\left(1.0 \times 10^{-2} \mathrm{cfu} / \mathrm{g}\right)$ while the Total viable count ranged from $\left(4.5 \times 10^{-7} \mathrm{cfu} / \mathrm{g}\right)$ to $\left(1.5 \times 10^{-6}\right.$ $\mathrm{cfu} / \mathrm{g})$. The percentage occurrence of the organisms isolated were Escherichia coli 42\%, Staphylococcus aureus 30\%, Pseudomonas spp 18\%, Bacillus spp $6 \%$ Serratia spp $2 \%$. This contamination may however not have deadly consequences if the skins or rinds were to be removed off before consumption. The microorganisms present in fruits and vegetables as shown in this study may be as a result of the poor hygienic production and transport facilities. The isolation of bacteria such as Staphylococcus aureus, Staphylococcus epidermidis, Bacillus species, Escherichia coli, Proteus species, Pseudomonas species, Klebsiella species, shows that fruits could act as a means for the spread of both pathogenic and opportunistic microbes. The study indicates a high total bacterial count which exceeded the microbial limit for fruits and vegetables which ranges from $<10^{2}$ $-10^{3}$. These organisms isolated are also collaborates to those isolated [13-14]. Isolation of Escherichia coli (coliforms) and enteric bacteria from fruits \& vegetables indicates the presence of faecal contamination [15], they could also be linked to the use of human manure. Also, isolation of environmental isolates such as Pseudomonas and Bacillus may be indicative of soil contamination. The isolation of skin commensals such Staphylococcus epidermidis and Staphylococcus aureus [16], may serve as link to contamination by handlers, either during transportation or post-harvest processing. Hydrogen peroxide was more effective than ethanol probably because it lasted for a longer time on the surfaces of the samples. The occurrence of antibiotic resistant microbes in fruits and vegetables constitutes a great health implication in developing countries [4]. From our observations, it is evident that fruits and vegetables could act as a potential vehicle for transmission of pathogenic organisms on fruits and vegetables. Infections and diseases caused by the pathogens are urinary tract infection, Abdominal and pelvic infection, pneumonia, meningitis, cellulitis, bacteremia etc From our observations, it is evident that fruits and vegetables act as a potential vehicle for transmission of pathogens and pose serious health issues to humans and other animals. Fruits and vegetables are contaminated from the farm due to animal waste and during all the processing stages. Also humans, soil, water and animal harbor these pathogens.Fruits and vegetables seeds should be properly stored to prevent contamination before and after planting. They should be kept in a closed vessel or storage cans in market to prevent contamination. Their surfaces should be cleaned always after been touched to prevent contamination due to Staphylococcus aureus. Fruits and vegetables should be hygienically handled and properly cleaned before eating to prevent faecal contamination.

\section{References}

[1]. Garrett E.H. (1999) Fresh-cut produce. In: Blakistone B.A. (eds) Principles and Applications of Modified Atmosphere Packaging of Foods. Springer, Boston, MA. https://doi.org/10.1007/978-1-4615-6097-5_6.

[2]. Hannan, A., Rehman, R., Saleem, S., Khan, M.U., Qamar, M.U. and Azhar, H. (2014). "Microbiological Analysis of Ready-to-eat Salads Available at Different Outlets in Lahore, Pakistan". International Food Research Journal, 21(5):1797-1800.

[3]. Jung, Y., Jang, H. and Matthews, K.R. (2014). "Effect of the Food Production Chain from Farm Practices to Vegetable Processing on Outbreak Incidence. Microbial Biotechnology, 7(6):517-527.

[4]. Razzaq, R., Farzana, K., Mahmood, S. and Murtaza, G. (2014). "Microbiological Analysis of Street Vended Vegetables in Multan City, Pakistan: A Public Health Concern". Pakistan J. Zool, 46(4):1133-1138

[5]. Barth, M., Thomas R.H., Zhuang, H and Breidt, F., (2009). "Microbiological Spoilage of Fruits and Vegetables" Compendium of the Microbiological Spoilage of Foods and Beverages, Food Microbiology and Food Safety.

[6]. Ray B, Bhunia AK (2007). Fundamental Food Microbiology. 4th Edn.,CRC Press, USA., p 492. 
[7]. Adebolu TT, Ifesan BO (2001). Bacteriological quality of vegetables used in salads. Niger. J. Microbiol. 15(1): 81-85

[8]. Uzeh RE, Alade FA, Bankole M (2009). The microbial quality of prepacked mixed vegetable salad in some retail outlets in Lagos, Nigeria. Afr. J. Food Sci. 3 (9): 270-272.

[9]. Bukar A, Uba A, Oyeyi TI (2010). Occurrence of some enteropathogenic bacteria in some minimally and fully processed ready to - eat foods in Kano metropolis, Nigeria. Afr. J. Food Sci. 4(2): 032-036.

[10]. Akhtar, S., Sarker, M.R and Hossain, A. (2014). "Microbiological Food Safety: A Dilemma of Developing Societies". Crit Rev Microbiol, 40:348-359.

[11]. Uyttendaele, M., Moneim, A.A., Ceuppens, S. and Tahan, F.E. (2014). "Microbiological Safety of Strawberries and Lettuce for Domestic Consumption in Egypt". J Food Process Technol, 5:308.

[12]. Shrivastava Shobha (2014)Bacteriological analysis of Fresh vegetables and Fruits of local market and effect of Pretreatment by Antimicrobial agents on their Quality . International Research Journal of Biological Sciences Vol. 3(11), 15-17.

[13]. Mathur, A., Joshi, A. and Harwani, D. (2014)." Microbial Contamination of Raw Fruits and Vegetables". Internet Journal of Food Safety, 16:26-28

[14]. Ankita, R. (2010). "Bacteria Load on Street Vended Salads in Juipur City, India". International J. Food safety, 12:136-139

[15]. Issa-Zacharia, A., Kamitani, Y., Muhimbula, H.S. and Ndabikunze, B.K. (2010).“A Review of Microbiological Safety of Fruits and Vegetables and the Introduction of Electrolyzed Water as an Alternative to Sodium Hypochlorite Solution" African Journal of Food Science, 4(13):778-789.

[16]. Abdelnoor, A.M., Batshoun, R. and Roumani, B.M. (1983). "The Bacterial Flora of Fruits and Vegetables in Lebanon and the Effect of Washing on the Bacterial Content". Zbl Bakt Hyg I Abt Orig B, 177:342-349. 